Human Relations Special Issue: Food, Work and Organization

Every Bite You Take...Food and the Struggles of Embodied Subjectivity in Organizations

\author{
By Michaela Driver, Ph.D. \\ Department of Management and Marketing \\ East Tennessee State University \\ Box 70625 \\ Johnson City, Tennessee 37614-0625 \\ Tel: (423) 439-5593 \\ Fax: (423) 439-5661 \\ E-mail: driver@etsu.edu
}




\title{
Every Bite You Take...Food and the Struggles of Embodied Subjectivity in Organizations
}

\begin{abstract}
The purpose of this paper is to offer new insights on subjectivity in organizations by examining discourses of food and their implications for how the self is constructed and embodied at work. To this end the empirical material, consisting of 35 narratives about food in organizations, is explored from different vantage points including hermeneutic, critical and postmodern perspectives. Themes examined include discourses in which food practices are associated with social activities and organizational care but also with controlling the self and others and as embodied performances of conflicting ethics of production and consumption. The implications of the various perspectives are discussed highlighting the role of food discourse for more creative embodiments of subjectivity in organizations.
\end{abstract}




\section{Introduction}

This is a paper about food in the workplace in which particular foods come into view not "as invariant objects...but rather as 'things' that materialize for people as diverse social practices" (Valentine, 2002: 3). Specifically, the paper is about food practices as they are articulated in discourse that may be interpreted within and across a number of different theoretical perspectives. Among other things, this discourse provides insight about how individuals struggle with subjectivity as a dialectical movement between "embodied experience" (Kerfoot, 2000: 234) and the body "as a variable boundary, a surface whose permeability is politically regulated, a signifying practice within a cultural field" (Butler, 1990). Within this dialectic, food plays a significant role as that which crosses and helps to socially construct the boundaries of the body (Lupton, 2000). As such the paper explores food practices as they are situated at the crossroads of the body's performativity (Butler, 1993) where "the body becomes a project to be fashioned and refashioned amid different [organizational] discourses" (Kerfoot, 2000: 234).

The paper focuses on discourse as a perspective and method of qualitative research (Alvesson and Skoldberg, 2000) because it offers a wide variety of approaches to language (Boje, Oswick and Ford, 2004) and reflexivity (Harley, Hardy and Alvesson, 2004). Importantly, discourse offers glimpses into the construction of subjectivity (Davies and Harre, 1990; Potter and Wetherell, 1987), including its psychodynamic dimension (Marshak, Keenoy, Oswick, and Grant, 2000). Finally, discourse highlights the contested nature of such constructions in organizations (Sveningsson and Alevsson, 2003) and how subject positions are mutually performed between researchers and 
research participants (Brown, Humphreys, and Gurney, 2005). The paper proceeds as follows. As shown in Table 1, I use a framework loosely based on reflexive methodology (Alvesson and Skoldberg, 2000) to introduce four perspectives on discourse of food in organizations: empiricism, hermeneutics, critical theory and postmodernism, adding a fifth one I call psychoanalysis.

\section{$\underline{\text { Insert Table } 1 \text { about here }}$}

The empirical perspective introduces the narratives collected for the study providing information on methodology and first-level interpretations. Within the hermeneutical perspective, I focus on how various food practices are interpreted by research participants and within the critical perspective I examine how food discourses reiterate power, control and the marginalization of others. From a postmodern perspective I explore how food practices are implicated in the performativity of the body and from a psychoanalytic perspective I reflect on food discourse relative to the construction and coconstruction of the self. The paper concludes by discussing the contributions of the five perspectives to the study of food discourse and subjectivity in organizations.

\section{Empirical Perspective: Narratives of Food}

For this study I collected 35 narratives also called stories as the term I used with research participants who were asked to write stories about food in organizations. The narratives were not literary stories but rather fragments of discourse that storytellers might draw on to construct their subject positions evoked at the request to tell me anything having to do with food in their workplace. Instructions were given verbally to all participants and were not formally scripted but in general followed the same outline. I 
explained that I was looking for volunteers to participate in a research project and that participants should recount stories about events or occurrences that had to do with food in their workplaces. As such I encouraged participants to provide grounded and reflective rather than projective and fictional stories. By using the term story I hoped to elicit narratives reflecting subjectivity in its more emotive qualities (Boje, 2001; Gabriel, 2000) while still allowing a focus on discourse and reflexivity (Alvesson and Skoldberg, 2000).

35 individuals came forward and were selected to share their stories. Subsequent interpretations therefore reflect the limitations imposed by the self-selection of participants inherent in this design. The research participants are working students in current or past courses I teach, who volunteered to write something without receiving credit or any other reward. All of them wrote on their own time and outside of class and did so by creating electronic documents and then emailing them to me providing on average 48 lines for a total of 1674 lines of text over the course of four months with some of them writing several times in response to follow-up questions for clarification. The narratives cover a range of organizations both in size and industry with participants holding positions from front-line employee to midlevel manager in healthcare, retail, financial services, public administration, manufacturing, hospitality, consulting, military, chemicals, automobile racing and telecommunications. Each narrative was numbered from 1 to 35 and line-by-line. I refer to them by naming the narrative number first and the line number second so that (1/17-18) would refer to narrative 1 lines 17 to 18 . I examined each narrative first as a stand-alone story and then looked for recurring themes by aggregating and searching for patterns across the narratives (Fineman and Sturdy, 1999) 
reiterating this process as I linked the themes to various theoretical perspectives (Alvesson and Skoldberg, 2000).

Within reflexive methodology: "Empirical material should be seen as an argument in efforts to make a case for a particular way of understanding social reality, in the context of a never-ending debate [italics in original]" (Alvesson and Skoldberg, 2000: 276). Therefore, I see the material not as reliable and valid proof but rather as one argument in a debate. As an argument, the material is influenced by the theoretical ideas I draw from and the case I seem to make or have [conveniently] found in the narratives (Alvesson and Skoldberg, 2000). For instance, first-level interpretations of the narratives reflect research I found describing food as surprisingly ubiquitous in organizations (Ford, McLaughlin, and Newstrom, 2003) with food described as being at workstations, on counters and desks, as well as in meeting, conference and break rooms. Seven out of 35 stories explicitly address the theme of food as being omnipresent. Food is described as "constantly available" (2/56) or "readily available" (4/53) with one narrator emphasizing that: "Basically, there is ALWAYS food at work" (1/3).

Foods mentioned across the 35 narratives include donuts, pizza, cookies, brownies, candies, cakes, pies, danishes, chips, muffins, cupcakes, chocolate, lollipops, popcorn, pretzels, mints, ice cream, candy bars, sandwiches, barbecue, ham, sausages, chicken strips, breasts and tenders, rib eye steaks, barbecue, biscuits, hotdogs, hamburgers, jerky, cheddar rounds, oatmeal, breakfast bars, protein bars, yogurt, fruits, vegetables, salads, Chinese, Mexican, Japanese and Italian takeout, fast and home-cooked foods and deserts, shakes, sodas, sports drinks, juice, and coffee as well as brands like 
Little Debbie snacks (2/26), Otis Spunkmeyer chocolate chip cookies (4/61), Keva juice (12/29), and Bo Berry Biscuit from Bo Jangles (12/127).

All 35 narratives contain descriptions of food related events such as birthday and Christmas parties, thank-you-for-a-job-well-done celebrations, award celebrations, new employee and going away parties, baby showers, holiday celebrations, picnics, luncheons, cookouts, training sessions, workshops, new employee orientations, monthly meetings, CEO-talks, inventory days, Fridays or very busy days $(1 / 4,4 / 59,6 / 3)$, and other special and often regular events such as dessert day (9/13), fun day (10/3), ice cream day (25/2), cake day (34/20), and Cookie Fridays (31/11). Finally, seven out of 35 narrators explicitly position food practices as central to organizational activities making comments such as: "Events were always planned around the food" (29/4) and "Food is an extremely integrated part of the routine for everyone in the offic"(10/1-2).

\section{Hermeneutic Perspective: Food, Rewards and Social Activities}

Further inquiry into the meaning of the narratives (Alvesson and Skoldberg, 2000) led me to focus on the theme of how food practices are interpreted relative to employee productivity and morale in the context of the discourse of Human Resource Management strategies (Ford et al., 2003). In the narratives food consumption is described as a "pick me up" (1/15), that "keeps us from falling asleep in meetings" (1/25) and as a means for improving training: "If we were just to have the routine trainings and that is it, then I feel like my employees would maybe not remember as much as if they did if food was around" (12/20-22). 27 out of the 35 narratives address this theme by interpreting food gifting and consumption as an all-purpose reward or as a thank you for a job well done (4/36). One narrator writes: "I use food as a reward to my employees" (12/16-17) and 
another recounts: "They have the cook-outs to celebrate, a thank you for a goal met, and morale purposes" (5/31-32). Nine narratives contain one or more references to how food is associated with enhanced morale and even joy (2/53). One narrator comments: "I think the employees are happier on the days we have cake (could just be a sugar buzz!?!). I think they like knowing we do something for them!" (34/14-16)

A related and fairly frequent theme in the narratives seems to be that food offerings, particularly of foods that are labeled as comforting $(5 / 23,11 / 32)$, are associated with a more caring side of organizations $(2 / 34-5,4 / 35,4 / 38)$. Food is described in terms alluding to childhood memories (1/1-2) and feeling good (4/31) and with child-like affection as a "goodie" (3/7) or a "yummy treat" (4/78) associated with love (2/2) and indulgence in defiance of parental authority (4/75-77). The consumption of certain foods is said to make people "happy" (4/17) and excited: "[A]ll the other women get very excited when something sweet is brought in for everyone to munch on" (9/8-9). In the narratives food consumption and preparation is associated with maternal love (Charles and Kerr, 1988) as in "freshly baked" foods (4/61) or in the statement: "But, on Fridays we would bake cookies for us and all of the customers. All day we would bake batches of cookies, and everyone really enjoyed 'Cookie Fridays' at the bank” (31/9-11).

Four of the narratives also describe food gifting and consumption as a perk or benefit $(1 / 3,1 / 20,6 / 4,31 / 2-4)$, which implies that food discourse also draws on more instrumental interpretations in which food gifting may be seen as having exchange value. Several of the narratives position food offerings as practices designed to entice individuals to attend meetings, events, training sessions and orientations (1/25, 2/12, $2 / 13,5 / 10,6 / 7-8)$. One story in particular offers an interpretation of food gifting as a 
discourse of negotiation: "Since I was going to have more free time, I was hoping I would be able to get more hours. My boss, who is the only male, in a branch with seven other women, sat down with me to make my schedule. He wanted to make a deal which consisted of me coming in 2 hours earlier every day and ALSO included me baking a cake or dessert each week and bringing it to work" (9/2-6). I will return to some of the issues that may be raised in this narrative about power (the person offering food is the subordinate) and gender differences (the person is a woman and the food is a home-made dessert) at a later point.

For now, I would like to focus on the idea that in the narratives food practices emerge as being situated in a liminal space where boundaries become blurred (Sturdy, Schwarz and Spicer, 2006). For instance, food discourse seems to blur boundaries between the organization as selflessly caring, a place where one should enjoy food to feel good, and the organization in which the favor of food gifting must be exchanged for more effort. In the narratives food discourse seems to blur the boundaries between productivity and consumption, work and fun (Crawford, 2000) so that it seems no longer clear whether food gifting and consumption are designed to be enjoyed for their own sake or to increase time and effort spent by employees at work, e.g. the dinner meeting (7/5), the 7:30 AM breakfast meeting with ham and sausage (2/73) or the 5 am staff meeting with donuts (5/9-10). One narrator comments: "On busy occasions, our manager would treat us to pizza or sub sandwiches" (11/14-15) and another recounts: "I pretty much ate while I worked, which is pretty usual for me at breakfast time" (12/81-82). Food practices exist in a liminal space between non-work and work with food consumption also described as providing a space free of work where one can take a break (1/46) (2/76-77), or a respite 
(2/67). Such breaks are welcomed and important: "I cannot even begin to describe how nice it is to be able to leave work even for just one hour [for lunch]" (12/70-71). Another narrator recalls food consumption as being a respite from military duty: "Eating was usually a time to relax and kind of unwind, we could take some of our gear off and remember what it was like to not carry an extra 100 lbs everywhere you go" (27/12-14).

33 out of 35 narratives address the theme of food consumption as a practice that has to do with or supports social activities referred to explicitly in this term $(1 / 46-47,2 / 6$, 2/68) or in statements such as: "In our office, food has become a centralized social opportunity" (10/10). Food discourse here seems to blur the boundaries between work and leisure when, for example, employees get together to eat outside of work but discuss work-related issues $(1 / 39-41,19 / 24-25)$. It also seems to blur boundaries between friendship and work relations: "We all ate together on Fridays and it made us all great friends. I guess you could say that we really came together through food" (16/6-7). Several narratives also draw on discourses of food associated with intimacy: "The food enabled everyone to form a circle of "trust'" (11/20). Narrators seem to interpret food consumption in association with opening up to and having closer relations with others: "It started out very casual and a few weeks into it we were all discussing very personal matters, as a matter of fact they were the first ones to learn that I was pregnant with my first son...we learned to really work as a team instead of individuals, all because of food" $(16 / 25-31)$.

\section{Critical Perspective: Food and the Other}

I now examine food discourses with a view toward the normalization of power and the marginalization of certain groups (Spivak, 1996). Eight narratives specifically 
draw on healthism, a medicalized discourse warning of the risks of undisciplined food consumption (Crawford, 2000), by mentioning the importance of eating healthy foods such as fruits, vegetables and yogurt (2/23-24) (14/21-22). While some of the narrators stress their employer's "healthy eating program" (5/6) offering a "plethora of literature on health related subjects" (5/21) and "healthy alternatives in vending machines" (5/6-7), most of the narrators focus on the contrast between unhealthy foods that are widely available and the healthy alternatives that may be promoted in workplace wellness programs (2/28). These include free preventive dental care, health spa and gym memberships (1/7-10) (5/4-5) and various exercise (like walking routes through stores) and nutrition programs with opportunities for employee awards $(5 / 1-5,5 / 6)$. Several of the narratives seem to address the latent contradiction of consuming foods that may be healthy but thereby interpreted as being less rewarding and vice versa: "I really think that it is embedded in our culture that whenever you have done something that deserves a reward, you would not think of veggie trays or fruits as rewarding??? I know that my employees would much rather have Fazolis [Italian food] or something like that instead of tossed salads. In a way I wish that healthy foods weren't viewed as unrewarding, because if they weren't then I think that America would not have so many problems with obesity, diabetes, heart problems, etc." (12/152-158).

What seems noteworthy about this narrative as well as the larger discourse of healthism that it draws on is that while food risks are discussed almost obsessively (Murcott, 1998), little concrete information is known by most individuals beyond the association of health and slimness (Charles and Kerr, 1988). The discourse of healthism has become tied to a cultural ideal of thinness, which is associated with gender, class and 
ethnic differences such that being overweight marks a person as unhealthy and, importantly, as marginalized "other", a stigma for women, the poor and the lower classes (Beardsworth and Keil, 1997; Charles and Kerr, 1988; Chernin, 1981). In the narratives it is mostly women who have weight problems and are identified as unable to resist the urge to consume food (1/31-39). One narrator recalls overweight women "rustling through the snacks" (4/65-66) while another recounts: "Well, the ladies at the office are always talking about eating healthy, but when you eat as often as they do, the diets they are always starting do not work. I don't tell them that...I always laugh when I see the ladies sipping coffee enjoying doughnuts or cookies. What a breakfast! They usually have a salad or sandwich for lunch. That wouldn't be so bad if they didn't keep candy and snacks on hand" (14/19-27).

As this narrator knows but doesn't tell "the ladies", it is understood that it is women who are obsessed with the making and consuming of food, especially unhealthy food: "The three women of the office usually make the cakes for each other...One woman loves chocolate and chocolate cake, but does not want to eat a whole cake at home by herself, so she makes a delicious cake and brings it in for us" (18/21-25). Another narrator comments: "The majority of the employees in the office were women. We would trade various recipes and even have cookie swaps during Christmas" (29/2-4). Women are described as valuing food for their social relationships while men are described as disassociated from food, particularly sweet foods: "men don't eat lollipops" (4/51). One narrator recounts: "The men in the Business Office usually just brought things that they had stopped and bought at the grocery and sometimes they didn't bring anything at all, there were only two men and they were both in administrative positions. 
All of us girls would cook and it just seemed to be easier to come together and talk over food" (16/21-25).

Women are also described as being "always on a diet" (2/51) and as inhibited in their food consumption: "[I]f we have pizza at work, the girls probably don't eat as much as they would had they been at home eating it. Most likely because it's a social atmosphere where subconsciously they feel like they're being critiqued (21/138-140). Women seem worried while men seem unencumbered: “One male co-worker eats an entire bag of chips with dip and dessert everyday during break"(21/248-249). Another narrator comments: "Right now, we just hired about 8 new people so there are about 5 males working with us. It seems that on break they don't care that they are at work because they eat a lot. One new guy had 2 powerade drinks and 4 packs of crackers, I think the girls had maybe a bag of chips or a pack of crackers. So there seems to be a difference in male eating habits and female eating habits at work too" (21/150-154). Women appear as ambiguous others, as both the traditional food and caregivers (Charles and Kerr, 1988) and objects of a thin-female ideal (Chernin, 1981).

The food narratives reiterate that bodies at work are disciplined and docile, as embodied males (McDowell, 1995), and that there is pressure to demonstrate disciplined eating if one wants to be seen as a good manager (Brewis and Sinclair, 2000). Therefore, controlled food consumption while justified within the healthism discourse also implicates power over the self and others (Chernin, 1981). For example, in the sense that men are positioned as indifferent to food or that managers are described as valuing healthy foods (2/23), males and individuals of higher rank may be seen to exert control over their bodies and therefore to be perceived as more powerful. Alternatively, those 
who do not demonstrate such control may be seen as less powerful: "[E]veryone gives my boss a hard time about eating so much of the dessert" (9/34-35). This in turn may require reasserting power in subtle ways: "My boss loves to eat and since all of us girls seem to always be on a diet, he never gets any good treats or sweets...There has also been one time, when one of my coworkers loved the dessert so much she was eating a large portion of it, and when the last two pieces were left my boss, purposely reminded her about her diet, hoping that she would not eat the last part of it. Even though it was all said and done in a joking fashion, she gave up the last piece to him, and in the end they both were happy" (9/6-32).

In nine of the narratives food consumption and even the presence of food is positioned as a continuous threat to control. The desire for food undermines weight control (2/48) and makes diets a constant but futile attempt at regaining control: “[E]veryone is on a diet "again???"(1/12) One narrator describes in detail how everyone is consuming food while on diet and that one man still eats what is offered even though he had gastric bypass surgery stapling his stomach up to the size of a fist causing him to vomit should food be consumed excessively (2/51-52 and 2/61-66). The narratives also position the consumption of certain foods as hard to resist: "Since, all the other women diet throughout the week and hardly ever eat anything sweet, when a dessert or treat is brought in, they devour it...”(9/10-12). Another recounts: "Yesterday, some people at work ordered pizza and my boss (who is dieting) refused to have even one piece. However she admitted it was very hard for her to watch them eat because the smell and the 'mmm's' that she heard made the pizza very enticing"' (21/160-163). 
Food consumption is also implicated in the control over others as people are asked to share food even if they do not want to and berated when they refuse. One narrator describes social pressure to eat at work (2/54) and how one employee is "taunted" for not eating (2/56). Another narrator describes how difficult it may be to resist being controlled when food is involved: "I think there is pressure no matter what, especially if you have any kind of personal relationship with management and I know from personal experience I have just not liked something that the hospital had catered in and not wanted to eat and had comments like 'What are you too good for Bar-B-Q?' Just things like that always seem to add pressure to gatherings that should be fun. These things can sometimes be very stressful" (16/47-49).

Processes of othering (Spivak, 1996) may be reflected in food discourses so that those who reject food are themselves rejected in some way. This seemed particularly relevant in one narrative about being a vegetarian among non-vegetarian colleagues: "When they found out I was a vegetarian their first instinct was to ask me if it would be alright to just pull the meat off the pizza...”(21/31-32); “During these outings I choose not to go because if the meeting has lasted through 'dinner' hours, I want more sustenance than a grilled cheese sandwich. Plus at $9 \mathrm{pm}$ on a Thursday I am in no mood to explain why I am a vegetarian or why I'm not eating or why I can't just get a salad" (21/71-74). In this narrative again there seems subtle pressure to control others through food consumption as the marginalized other has to justify different food choices and is pressured to eat the food even if his/her particular needs are not accommodated. 


\section{Postmodern Perspective: Food and the Body}

I now explore the narratives and issues of control from a postmodern perspective focusing on the body as an interaction of embodiment, discourses and institutional power (McDowell, 1995). The body, particularly in the workplace, is a project that has materiality and is socially performed in continuous tension of the disembodied, rational, and male versus the embodied, irrational, even grotesque and threatening female (McDowell, 1994; 1995). Embodied subjectivity is constructed in the contested discourse of modern capitalism and its opposing ethics of production versus consumption, in which the body is disciplined, compliant, self-controlled and ready to perform with machinelike precision, while at the same time receptive to hedonistic pleasures and uncontrolled excess (Crawford, 2000). Eating is both a descent into the grotesque, the bodily, the uncontrolled as well as a source of pride and pleasure from self-mastery; it is both transgression and atonement, a banality and an act with irreversible consequences (Lupton, 1996).

This contradiction produced at the site of the body (Gibson-Graham, 1996) emerges in the narratives as a constant struggle with food. Food is described as “tempting" (4/55) or as a "temptation" (4/50) one "admits (4/50) to "indulge" in (4/50). People are said "to give in" to food (4/63) and overeating is confessed like a sin "the most shameful part of my indulgence" (4/57). Giving in to food is judged as a moral weakness (4/65) while resisting food is cause for admiration as "you are so good" not to eat this food (2/59-60). Food consumption is associated with guilt and one must "resist the urge" to eat (2/60). Food is narrated as a "yummy treat" but one must "maintain 
avoidance of such unhealthy foods" (4/75-77) as excess threatens obesity and death $(4 / 85)$.

Some of the narratives are meticulous in detailing the personal dilemmas involved with food at work: "This morning I went to Pals (fast food restaurant) for Breakfast, which I rarely do because I usually eat oatmeal or something healthy after I arrive at work... I have to say that indulging in cheddar rounds and a jelly biscuit every once in a while is pretty nice" (12/54-64). "This morning I ate fruit and walnut salad from McDonalds...I also ate a protein bar. I felt really good about this meal, because it was very healthy and it did not make me feel guilty" (12/93-96). "He brought a box by the office for the staff, and I had to eat half of one [donut]. So much for my healthy eating today!!! I guess it is okay to indulge every once in a while, but I think the important thing is portion control" (12/97-100). "I guess I would have to say that there is definitely mixed emotions for me with food and the workplace. I work out 4-5 times per week and I try to be very health conscious, but sometimes it is hard not to indulge in foods that are not really good for you like donuts, cookies, etc. I think the key is that it is okay to eat foods such as this, but I think that portion control is what a person should focus on. I personally think that one of the major problems with Americans and obesity is that they have no portion control???" (12/131-137) "Sometimes, I do wish that food were not a part of work. But, it does give me and my employees something to look forward to?" (12/160161)

Particularly, in this last narrative the struggle over embodied subjectivity comes through. There is constant toiling and agonizing over healthy versus unhealthy foods and various transgressions and guilty pleasures. The struggle to construct subjectivity in 
relation to food is interplay of conflicting and complimentary desires producing and produced within larger social structures that remain invisible within the narcissistic obsessions of individuals over body image and maintenance (Turner, 1996). While the narrator momentarily reflects on the larger context like "American culture", most of the institutions, discourses and ideologies within which bodies are constituted (Frank, 1991) remain invisible; power that is embodied and normalized and therefore hard to contest (Bordo, 1990). Within this normalized struggle, questions of the body seem disassociated (Frank, 1991) with the self coming in and out of focus as a distant and alienated voice.

\section{Psychoanalytic Perspective: The Imaginary Subject of Food Narratives}

In this section I explore in greater depth the idea of alienation and subjectivity from a psychoanalytic perspective (Lacan, 1977a;b; 1988a;b) and reconnect with but also reflect further on issues of research methodology touched on in the empirical perspective. In the narratives the self is presented as having the power to identify and satisfy desire:

"The Pals breakfast did make me happy" (12/64-65). The self is also presented as a stable, definitive object whose coherent identity crystallizes around food practices: "I returned back to work and ate my salad that Ed had brought me. I felt very good about this because it was healthy. I used to hate salads growing up, but now I thoroughly enjoy them" (12/114-116). From a psychoanalytic perspective, such presentations of the self in discourse are imaginary constructions by which the speaker tries to cover up that the subject so represented is fundamentally lacking. It is merely a placeholder in a larger order in which others give meaning and therefore determine one's desires, such as internalized friends, parents, institutions and the conventions of language itself. The more the imaginary self threatens to unravel, the more it must be validated by articulating 
repeatedly who the person is and what they want: "I find myself able to maintain that avoidance of unhealthy foods" (4/76-77). Moreover, the imaginary self is commonly validated by attempting to control interactions with others: "I did eat less than I would have... because I felt self-conscious about what people would think if I went back for seconds" (33/39-42).

With this in mind, I would also like to explore how I may have colluded with the narrators to co-construct the imaginary selves in the food narratives. In the role of researcher/scientist presented to participants when I asked them to write their stories, I constructed myself in relation to the participants as the subject-supposed-to-know (Lacan, 2001). Through interactions in discourse, this subject-supposed-to-know can tell another subject something about who they are and what they want by responding in ways that validate imaginary constructions. By thanking them for their contributions, asking questions and apparently at some point being happy with their answers, I signaled that they not only understood but also satisfied my desire. In this sense I helped to maintain their imaginary sense of self as I apparently understood and approved of what they were telling me. At times this imaginary exchange with me as the subject-supposed-to-know surfaced such as when the narrators addressed me directly with comments like: "I hope this information helps" (12/161); or: "Ok, here it is. I am not sure that this is going to be as good as you are hoping but, some of it is at least mildly amusing" (1/1-2). It also surfaced as narrators commented on things they assumed I knew: "You know, it is weird how when unexpected things happen in your life such as this, you just don't seem to care about things that you normally do" (12/127-128); or when they addressed me as a familiar other who understands and might want to share their choices: "I decided to 
indulge somewhat and went to Bojangles to get a Bo Berry Biscuit. (They are very good if you have never tried one)" (12/142-144).

Consequently, it may not be enough to engage in reflexivity on the extent to which I co-constructed the empirical material by taking a multi-paradigmatic approach (Alvesson and Skoldberg, 2000). Rather reflexivity might be required as to what extent I engaged responsibly with participants' subjectivity (Glynos, 2002). Along those lines, I can reflect on the degree to which I let the respondents speak for themselves and how much voice I allowed them relative to my own (Wray-Bliss, 2003). I can say that I made every effort to let the participants tell their own stories and used questions with care so as not to influence them or signal what I might want to hear (Wray-Bliss, 2003). I can also say that I tried to provide a great deal of the narrators' own words within the constraints of a journal article and made only minor alterations for spelling. However, I cannot say that I helped the participants work through their imaginary constructions. Exploring how I could have done so by using an analytic approach (Lacan, 1988a) to increase awareness for the failures of the imaginary in the food narratives is beyond the scope of this paper. Nonetheless, as an aspect of reflexivity, it is perhaps constructive if not sobering to think about how my research may be implicated in alienating the participants by validating imaginary constructions of the self, including myself, as social scientist in pursuit of richer understandings (Alvesson and Skoldberg, 2000).

\section{Conclusion}

So far I have explored the narratives of food in organizations from five different perspectives: empirical, hermeneutic, critical, postmodern and psychoanalytic. In this section I would like to explore what each perspective seems to contribute to our 
understanding of food and subjectivity in organizations and discuss how the perspectives differ, overlap but also complement each other and then draw some conclusions about themes that seem to transcend them. The empirical perspective helped to situate the narratives of food in the context of organizational research and methods for data collection and analysis. It also offered a first look at food discourse in organizations allowing me to list the kinds of foodstuffs and food-related events mentioned in the narratives and to note the ubiquity of food practices in organizations.

The hermeneutic perspective made it possible to investigate in greater depth how food "materialize[s] for people as diverse social practices" (Valentine, 2002: 3). Specifically, the meanings and interpretations that may be attached to food discourses in organizations came into closer view. From this view, it was possible to see how food practices may be associated with organizational care and social activities, but also how they often constitute liminal spaces in which work and non-work activities as well as the public and private self overlap. The critical perspective in turn made it possible to obtain a view of issues of power and marginalization. From this perspective it was possible to see processes of othering with regard to gender or class and how power and control are normalized by drawing on discourses of healthism and disciplined food consumption.

The postmodern perspective provided further but also different insights into the issues of discipline and power uncovered in the critical perspective. It made it possible to focus on the individuals in the narratives as subjects struggling with their embodiment and the contradictions of production versus consumption ideologies. This perspective provided an important glimpse into how bodies are disciplined but also how they subvert this discipline (Butler, 1993). Finally, the psychoanalytic perspective provided insights 
about how food discourse relates to imaginary constructions of subjectivity and how the researcher may be implicated in this process.

What I have just described suggests that each perspective contributes something particular to our understanding of food discourses in organizations but also that there are overlaps between them. For example, there are overlaps between the critical and the postmodern perspectives, as both seem to reveal how food discourse is produced by and produces institutional power and ideologies of production and consumption. There are also overlaps between the postmodern and the psychoanalytic perspectives, as both address the struggles of subjectivity, and between the psychoanalytic and the empirical perspectives as both address the research process. Additionally, the five perspectives also complement each other as each offers progressively deeper and/or wider vantage points that taken together provide a richer understanding of the complexities of food discourses in organizations. For example, the empirical perspective provided an important glimpse of the surface of the narratives, while the hermeneutical perspective allowed me to zoom in on subjective meaning. The critical perspective made it possible to consider the wider context of such dynamics as power and control while the postmodern perspective allowed me to zoom in again to examine how such dynamics may be played out as struggles with embodied subjectivity. The psychoanalytic perspective continued the process of zooming in but also allowed me to reconnect to and come full circle with the empirical perspective touching on issues of the research process.

Finally, by providing complementary vantage points, two transcendent themes also emerge from the five perspectives, namely embodiment as a material and lived experience (Casey, 2000) and struggle as a contestation of discourses, institutions and 
ideologies (Turner, 1996). As to the first theme, what underlies but may not come clearly into focus in any one perspective is that food practices have meaning as well as materiality (Lupton, 1996) and are embodied as lived experiences in the narratives: "I can admit that when my boss gets a quiznos [fast food restaurant] sandwich, the smell makes me want to go to quiznos and get one as well. Also, seeing someone enjoying their food (licking their fingers, making 'mmm' sounds, etc) makes the food seem very appetizing, even if it's something with meat I'll still have a slight curiosity as to what they taste just because of how much they are enjoying it. I have no drive to eat the meat dish, but the feeling of knowing how they feel while they eat makes me want to eat something that gives me the same feeling (even if I'm not hungry)" (21/164-170). The dilemma here described by the narrator is a lived and sensual experience, one that can be tasted, touched, seen, heard and smelled.

Moreover, what comes into view by looking across but also beyond the five perspectives is that a focus on food in organizations pushes us to the limits of discourse and toward the recognition of embodiment encompassing the material conditions of work and the labor process (Cloud, 2005). For example, the narratives describe how managers have access to healthier foods (2/23) and can spend more time consuming food and doing so together: "The regular employees never get a chance to eat together. The lunch times are always divided so that the shift is always covered. There is never an opportunity for them to get together and socialize with a meal. The management team on the other hand is able to get together and eat in the break room with no problems" (28/4-8). Another narrator comments: "The managers tend to go out and eat. They tend to be gone longer than the regular lunch hours. They leave around 11:30 and get back to work around 1:00" 
(14/11-13). Food discourse as a reflection of material conditions in the labor process also highlights the importance of resistance (Thompson and Ackroyd, 1995). As one narrator recounts employees appropriate food related events as non-work: "No one worked or answered the phones; we just celebrated and had a great time socializing. People from other departments stopped by to visit and enjoy the food once they realized we were having a party...We have a 'master' calendar with everybody's birthday listed, so that we never miss a party" (18/7-22). As another narrator recounts, food may also be appropriated as something that does not just facilitate work occasionally but becomes a necessary requirement: “The phrase 'Let's do lunch!' is used so often that it seems work can only be done over lunch" (14/4-5).

The second transcendent theme that emerges from the five perspectives is that the struggle of embodied subjectivity is a way to denaturalize and contest discourses, institutions and ideologies (Turner, 1996). In the narratives I have tried to show how power may be normalized and embodied as narrators perform contradictory ethics of production and consumption (Crawford, 2000) and comply with organizational norms of fitness and discipline (Turner, 1996). However, a focus on food practices in the context of struggles of embodied subjectivity also highlights how existing norms may be contested or rather how they are always already being contested. For instance, the narratives offer glimpses of employees appropriating the ethics of consumption by eating too much or enjoying their food too much, which may be compared to employees appropriating organizational culture programs by believing too much (Fleming and Spicer, 2003). One narrator describes how a recent employee survey showed that the one thing all employees in the organization have in common is that: "We all love to eat" 
$(2 / 2)$. In this redefinition the organization is no longer a workplace where food is consumed at times but a place where food is consumed while work happens.

Moreover, while the organization as reflecting a performance ethic might encourage employees to enjoy their food, the employees may instead consume food for its own sake making excessive consumption an end in itself. For instance, narrators describe overeating (2/51) and eating even when not hungry (4/80). They describe endless food events and an endless food supply (1) and eating as "div[ing] in" (5/45), "digging in" (2/54), "devour[ing] it" (9/11) or "rack[ing] up" food (1/21). One narrator describes how "a posse of bodies hits the local diner" $(1 / 23)$ and then "we have a meeting and order more PIZZA!!!" (1/24) One narrator recounts: “My co-workers usually don't waste anytime to dig in either, they usually have their first taste before the bank even opens!" (9/18-19) In this sense, food discourse provides opportunities for creative performativity not only by appropriating excess as a transgression that is desirable (Butler, 1993) but as a radical externalization and embodiment of the production/consumption dialectic in which food practices come to believe and even produce for us (Fleming and Spicer, 2003). If as one narrator describes "[W]e were just to have the routine trainings and that is it, then I feel like my employees would maybe not remember as much as if they did if food was around" (12/20-22), then perhaps training is already creatively embodied as a food practice that remembers for us.

The point I hope to make is that the paper offers new avenues for the theory and practice of food discourse in organizations because it provides insights about subjects as bodies that lack control and threaten the discipline of disembodied organizations (Hassard, Holliday and Willmott, 2000) but also because it reveals the contradictions and 
tensions in the construction of subjectivity as both disembodied, the "I" with an invisible body, merely a tool in one's projects (Young, 1984), and embodied, the "I" of late consumer capitalism turning the body into an ever-important project of self-improvement and social presentation (Frost, 2005). In short, the paper contributes to our understanding of and hopefully lays the groundwork for further inquiries into embodied subjectivity in organizations around issues of control, desire, the relation to others and the self (Frank, 1991) examining food practices and the body's creative performativity (Butler, 1993) at the interstice of "god-like assurance and the embarrassment of the Freudian slip" (Frank, 1991: 51).

\section{References:}

Alvesson, M., and Skoldberg, K. 2000. Reflexive Methodology. London: Sage.

Beardsworth, A. and Keil, T. 1997. Sociology on the menu. London: Routledge.

Boje, D. M. 2001. Narrative Methods for Organizational and Communication Research, London, Sage.

Boje, D.M., Luhman, J.T. and Baack, D.E. 1999. Hegemonic stories and encounters between storytelling organizations. Journal of Management Inquiry, (8)4: 340-360.

Boje, D.M., Oswick, C. and Ford, J. 2004. Language and organization: The doing of discourse. Academy of Management Review, 29(4): 571-577.

Bordo, S. 1990. Reading the slender body. In Jacobus, M., Keller, E.F. and Shuttleworth, S. (Eds.). Body politics: Women and the discourses of science: 83-112. London: Routledge.

Brewis, J. and Sinclair, J. 2000. Exploring embodiment: Women, biology and work. In Hassard, J., Holliday, R. and Willmott, H. (Eds.). Body and Organization: 192-214. London: Sage.

Brown, A.D., Humphreys, M. and Gurney, P.M. 2005. Narrative, identity and change: a case study of Laskarina Holidays. Journal of Organizational Change Management, 18(4): 312-326.

Butler, J. 1990. Gender trouble. London: Routledge. 
Butler, J. 1993. Bodies that matter. London: Routledge.

Casey, C. 2000. Sociology sensing the body: Revitalizing a dissociative discourse. In Hassard, J., Holliday, R. and Willmott, H. (Eds.). Body and Organization: 52-70. London: Sage.

Charles, N. and Kerr, M. 1988. Women, food and families. New York: Manchester University Press.

Chernin, K. 1981. Womansize: The tyranny of slenderness. London: Women's Press.

Cloud, D.L. 2005. Fighting words: Labor and the limits of communication at Staley, 1993-1996. Management Communication Quarterly, 18(4): 509-542.

Crawford, R. 2000. The ritual of health promotion. In Williams, S.J., Gabe, J. and Calnan. M. (Eds.). Health, medicine and society: 219-235. London: Routledge.

Davies, B. and Harre, R. 1990. Positioning: The discursive Production of Selves. Journal for the Theory of Social Behavior, 20(1): 43-63.

Fineman, S. and Sturdy, A. 1999. The emotions of control: A qualitative exploration of environmental regulation. Human Relations (52)5: 631-658.

Fleming, P. and Spicer, A. 2003. Working at a cynical distance: Implications for power, subjectivity and resistance. Organization, 10(1), 157-179.

Ford, R.C., McLaughlin, F.S. and Newstrom, J. 2003. Questions and answers about fun at work. Human Resource Planning, 26(4): 18-33.

Frank, A.W. 1991. For a sociology of the body: An analytical review. In Featherstone, M., Hepworth, M. and Turner, B. (Eds.). The body: Social process and cultural theory: 36-102. London: Sage.

Frost, L. 2005. Theorizing the young woman in the body. Body and Society: 11(1): 6385 .

Gabriel, Y. 2000. Storytelling in organizations. New York, NY: Oxford University Press.

Gibson-Graham, J.K. 1996. The end of capitalism. Cambridge, MA: Blackwell.

Glynos, J. 2002. Psychoanalysis operates upon the subject of science: Lacan between science and ethics. In Glynos, J., and Stavrakakis, Y. (Eds.) Lacan and Science. London: Karnac: 51-88. 
Harley, B., Hardy, C. and Alvesson, M. 2004. Reflecting on reflexivity. Paper presented at the Academy of Management Conference, New Orleans.

Hardy, C. 2001. Researching organizational discourse. International Journal of Management \& Organization, 31(3), 25-48.

Hassard, J., Holliday, R. and Willmott, H. (Eds.). 2000. Body and Organization. London: Sage.

Kerfoot, D. 2000. Body work: Estrangement, disembodiment and the organizational 'other'. In Hassard, J., Holliday, R. and Willmott, H. (Eds.). Body and Organization: 231246. London: Sage.

Lacan, J. 1977a. Ecrits. New York: Norton.

Lacan, J. 1977b. The four fundamental concepts of psychoanalysis. London: Hoghart Press.

Lacan, J. 1988a. The seminar of Jacques Lacan, Book I: Freud's papers on technique 1953-1954. New York: Norton.

Lacan, J. 1988b. The seminar of Jacques Lacan, Book II: The ego in Freud's theory and in the technique of psychoanalysis 1954-1955. New York: Norton.

Lacan, J. 2001. Autres ecrits. Paris: Editions Du Seuil.

Lupton, D. 1996. Food, the body and the self. London: Sage.

Lupton, D. 2000. Food, risk and subjectivity. In Williams, S.J., Gabe, J. and Calnan. M. (Eds.). Health, medicine and society: 205-218. London: Routledge.

Marshak, R.J., Keenoy, T., Oswick, C., and Grant, D. 2000. From outer words to inner worlds. The Journal of Applied Behavioral Science, 36(2), 245-259.

McDowell, L. 1994. Performing body: bodily representation in merchant banks.

Environment and Planning D: Society and Space, 12: 727-750.

McDowell, L. 1995. Body work. In Mapping desire. Bell, D. and Valentine, G. (Eds.): 75-95. London: Routledge.

Murcott, A. 1998. The nation's diet. London: Longman.

Potter, J. and Wetherell, M. 1987. Discourse and social psychology. London: Sage. 
Spivak, G.C. 1996. Subaltern talk: Interview with the editors. In Landry, D. and MacLean, G. (Eds.). Selected Works of Gayatri Chakravorty Spivak: 287-308. London: Routledge.

Sturdy, A., Schwarz, M. and Spicer, A. 2006. Guess who's coming to dinner? Structures and uses of liminality in strategic management consultancy. Human Relations, 59(7): 929-960.

Sveningsson, S. and Alvesson, M. 2003. Managing managerial identities: Organizational fragmentation, discourse and identity struggle. Human Relations, 56(10): 1163-1180.

Thompson, P. and Ackroyd, S. 1995. All quiet on the workplace front? A critique of recent trends in British industrial sociology. Sociology, 29(4): 615-629.

Turner, B. S. 1996. The body and society. London: Sage.

Valentine, G. 2002. In-corporations: Food, bodies and organizations. Body and Society. 8(2): 1-20.

Wray-Bliss, E. 2003. Research subjects/research subjections: Exploring the ethics and politics of critical research. Organization, 10(2): 307-325.

Young, I.M. 1984. Pregnant embodiment: Subjectivity and alienation. Journal of Medicine and Philosophy, 9: 45-62. 
Table 1. Overview of the Five Perspectives

\begin{tabular}{|c|c|c|}
\hline Perspective & Key Characteristics & Sample Comments \\
\hline $\begin{array}{l}\text { Empirical: } \\
\text { Narratives of Food }\end{array}$ & $\begin{array}{l}\text { Introduction of the empirical } \\
\text { material and how it was } \\
\text { obtained, } 35 \text { narratives of } \\
\text { food, participants, first-level } \\
\text { interpretations, ubiquity of } \\
\text { foods and food-related events }\end{array}$ & $\begin{array}{l}\text { Food described as "constantly available" }(2 / 56) \text { or } \\
\text { "readily available" (4/53). "Basically, there is } \\
\text { ALWAYS food at work" (1/3). Dessert day }(9 / 13) \text {, } \\
\text { fun day }(10 / 3) \text {, ice cream day }(25 / 2) \text {, cake day } \\
(34 / 20) \text {, and Cookie Fridays }(31 / 11) \text {. "Events were } \\
\text { always planned around the food" (29/4) }\end{array}$ \\
\hline $\begin{array}{l}\text { Hermeneutic: } \\
\text { Food, Rewards, } \\
\text { and Social } \\
\text { Activities }\end{array}$ & $\begin{array}{l}\text { Further inquiry into the } \\
\text { meaning of the narratives, } \\
\text { second order interpretations, } \\
\text { food narratives in the context } \\
\text { of employee productivity, } \\
\text { morale, organizational care, } \\
\text { blurred boundaries between } \\
\text { work and non-work, food } \\
\text { practices and social activities }\end{array}$ & $\begin{array}{l}\text { "They have the cook-outs to celebrate, a thank you } \\
\text { for a goal met, and morale purposes" (5/31-32), } \\
\text { Food is described as a "goodie" (3/7) or a "yummy } \\
\text { treat" (4/78) and is associated with love (2/2). "I } \\
\text { pretty much ate while I worked, which is pretty } \\
\text { usual for me at breakfast time" (12/81-82), "We all } \\
\text { ate together on Fridays and it made us all great } \\
\text { friends. I guess you could say that we really came } \\
\text { together through food" (16/6-7) }\end{array}$ \\
\hline $\begin{array}{l}\text { Critical: Food and } \\
\text { the Other }\end{array}$ & $\begin{array}{l}\text { Food and the normalization of } \\
\text { power, discourses of } \\
\text { healthism and the disciplined } \\
\text { body, thinness as power, } \\
\text { gender and class issues, } \\
\text { women and lower-level } \\
\text { employees eat less healthy } \\
\text { foods, food consumption and } \\
\text { control, those who refuse to } \\
\text { consume certain foods are } \\
\text { marginalized }\end{array}$ & $\begin{array}{l}\text { "In a way I wish that healthy foods weren't viewed } \\
\text { as unrewarding, because if they weren't then I think } \\
\text { that America would not have so many problems } \\
\text { with obesity, diabetes, heart problems, etc." } \\
\text { (12/154-158). "Well, the ladies at the office are } \\
\text { always talking about eating healthy, but when you } \\
\text { eat as often as they do, the diets they are always } \\
\text { starting do not work" (14/19-22). "What are you too } \\
\text { good for Bar-B-Q?' Just things like that always } \\
\text { seem to add pressure to gatherings that should be } \\
\text { fun. These things can...be very stressful" (16/47-49) }\end{array}$ \\
\hline $\begin{array}{l}\text { Postmodern: Food } \\
\text { and the Body }\end{array}$ & $\begin{array}{l}\text { Food consumption in relation } \\
\text { to the body as an interaction } \\
\text { of embodiment and } \\
\text { institutional power, contested } \\
\text { discourse of modern } \\
\text { capitalism and its opposing } \\
\text { ethics of production versus } \\
\text { consumption, food } \\
\text { consumption as transgression } \\
\text { and atonement, constant } \\
\text { struggle with food }\end{array}$ & $\begin{array}{l}\text { Food is described as a "temptation" (4/50) one } \\
\text { "admits }(4 / 50) \text { to "indulge" in }(4 / 50) \text {. "He brought a } \\
\text { box by the office for the staff, and I had to eat half } \\
\text { of one [donut]. So much for my healthy eating } \\
\text { today!!! I guess it is okay to indulge every once in a } \\
\text { while, but I think the important thing is portion } \\
\text { control" (12/97-100). "I guess...there is definitely } \\
\text { mixed emotions for me with food and the } \\
\text { workplace...I try to be very health conscious, but } \\
\text { sometimes it is hard not to indulge in foods that are } \\
\text { not really good for you like donuts...(12/131-134) }\end{array}$ \\
\hline $\begin{array}{l}\text { Psychoanalytic: } \\
\text { The Imaginary } \\
\text { Subject of Food } \\
\text { Narratives }\end{array}$ & $\begin{array}{l}\text { Imaginary construction of the } \\
\text { self in the food narratives, co- } \\
\text { constructions between } \\
\text { researcher and research } \\
\text { participants, researcher as } \\
\text { subject-supposed-to-know }\end{array}$ & $\begin{array}{l}\text { "The Pals breakfast did make me happy" (12/64- } \\
65) \text {." I find myself able to maintain that avoidance } \\
\text { of unhealthy foods" (4/76-77) "I decided to indulge } \\
\text { somewhat and went to Bojangles to get a Bo Berry } \\
\text { Biscuit. (They are very good if you have never tried } \\
\text { one)" (12/142-144) }\end{array}$ \\
\hline
\end{tabular}

